\title{
Descrevendo Algumas Subjetivações de um Grupo de Licenciandos em Matemática
}

\author{
SILVA, Wanessa Mayara da ${ }^{1}$ \\ QUEIROZ, Simone Moura²
}

\section{RESUMO}

O trabalho apresenta resultados do recorte de uma pesquisa mais extensa, cujo objetivo foi descrever os possíveis processos de subjetivações e/ou agenciamentos que perpassaram o devir docente de 22 licenciandos em Matemática da UFPE, Campus Caruaru. Conduzimos a pesquisa em conformidade com a Filosofia da Diferença, propriamente, com obras desenvolvidas a partir de estudos dos filósofos Michel Foucault (1999), Gilles Deleuze e Felix Guattari (1994) e Suely Rolnik (1996). No percurso metodológico, propomos aos referidos discentes que respondessem um questionário, com cinco perguntas discursivas e, para a descrição dos dados produzidos utilizamos a abordagem qualitativa. Como resultados deste estudo, constatamos que, as possíveis subjetivações e agenciamentos apontados pelos discentes pesquisados, foram: a falta de opção, baixa concorrência, facilidade de conseguir um emprego, amorosidade pela docência, o gosto e facilidade de compreender a Matemática durante a Educação Básica.

Educação Matemática. Filosofia da Diferença. Subjetivação e Agenciamento.

Desejo. Devir Docente.

\section{Describing Some Subjectivations of a Mathematics Undergraduates Group}

\section{ABSTRACT}

The work presents results of the cut of a more extensive research, whose objective was to describe the possible processes of subjectivations and / or agencies that went through the teaching process of 22 undergraduate students in Mathematics at UFPE, Campus Caruaru. We conducted the research in accordance with the Philosophy of Difference, properly speaking, with works developed from studies by the philosophers Michel Foucault (1999), Gilles Deleuze and Felix Guattari (1994) and Suely Rolnik (1996). In the methodological

\footnotetext{
${ }^{1}$ Pós-graduanda Lato Sensu em Docência do Ensino Básico e Superior pela Faculdade Estratego. Graduada em Matemática. Email: wanessa.mayara12@gmail.com. Lattes: http://lattes.cnpq.br/5023202497195108. Orcid: http://orcid.org/0000-0003-0282-9739. 2 Doutora em Educação Matemática pela UNESP - Rio Claro. Professora adjunta da Universidade Federal de Pernambuco - Centro Acadêmico do Agreste. Email: simonemq35@gmail.com. Lattes: http://lattes.cnpq.br/0630970592118924. Orcid: http://orcid.org/0000-0002-3878-4619.
} 
path, we propose to the referred students to answer a questionnaire, with five discursive questions and, for the description of the data produced, we use the qualitative approach. As a result of this study, we found that, the possible subjectivations and agencies pointed out by the researched students, were: the lack of option, low competition, ease of getting a job, love for teaching, the taste and ease of understanding Mathematics during Basic Education.

\section{Mathematical Education. Difference Philosophy. Subjectivation and Agency.} Desire. Becoming a Teacher.

\section{Describiendo algunas subjetivaciones de un grupo de Licenciados en Matemáticas}

\section{RESUMEN}

El trabajo presenta resultados del corte de una investigación más extensa, cuyo objetivo fue describir los posibles procesos de subjetivación y / o agenciamiento que atravesaron a formación docente de 22 estudiantes de pregrado en Matemáticas de la UFPE, Campus Caruaru. La investigación fue realizada de acuerdo con la Filosofía de la Diferencia, propiamente, con obras desarrolladas a partir de estudios de los filósofos Michel Foucault (1999), Gilles Deleuze y Felix Guattari (1994) y Suely Rolnik (1996). En la ruta metodológica, proponemos a los estudiantes referidos responder un cuestionario, con cinco preguntas discursivas y, para la descripción de los datos producidos, utilizamos el enfoque cualitativo. Como resultado de este estudio, encontramos que las posibles subjetivaciones y agenciamiento señaladas por los estudiantes investigados fueron: la falta de opción, la baja competencia, la facilidad para conseguir trabajo, el amor por la docencia, el gusto y la facilidad para comprender las Matemáticas durante la Educación Básica.

Educación Matemática. Filosofía de la Diferencia. Subjetivación y Agenciamiento. Deseo. Convertirse en profesor.

\section{Descrivere alcune soggettificazioni di un gruppo di laureati in matemática}

\section{SOMMARIO}

Il lavoro presenta i risultati del taglio di un'indagine più ampia, il cui obiettivo era descrivere i possibili processi di soggettivazione e / o assemblaggio che sono passati attraverso la formazione dei docenti di 22 studenti universitari in Matematica dell'UFPE, Campus Caruaru. La ricerca è stata condotta in accordo con la Filosofia della Differenza, propriamente, con opere sviluppate dagli studi dei filosofi Michel Foucault (1999), Gilles Deleuze e Felix Guattari (1994) e Suely Rolnik (1996). Nel percorso metodologico, si propone che gli studenti segnalati rispondano ad un questionario, con cinque domande discorsive e, per la descrizione dei dati prodotti, si utilizza l'approccio qualitativo. Come risultato di questo studio, abbiamo scoperto che le possibili soggettificazioni e assemblaggi 
indicati dagli studenti indagati erano: mancanza di scelta, bassa competizione, facilità di trovare un lavoro, amore per l'insegnamento, gusto e facilità di comprensione della matematica durante l'istruzione di base.

Educazione matematica. Filosofia della differenza. Soggettivazione e Agenzia. Desiderio. Diventare un insegnante.

\section{INTRODUÇÃO}

$\mathrm{Na}$ contemporaneidade, os sujeitos são levados a escolher uma carreira profissional, desde a infância. Muitos perguntam a eles: "profissionalmente, você pretende se tornar o que quando 'crescer'?" Talvez seja fácil nessa faixa etária responder a essa pergunta, pois são coisas que ocorrerá a eles no porvir, em que, muitas vezes, o que no mínimo precisa suceder é admirar alguma profissão ou reproduzir o que mais ouve ao seu redor, onde as mídias ou pessoas próximas a eles subjetivam ${ }^{3}$ nas respostas.

No entanto, quando chega à adolescência, precisam escolher caminho (s) que os mesmos pretendem trilhar no futuro, que já é próximo, quer dizer, eles têm a liberdade de decidir se querem continuar ou parar de estudar. São várias opiniões a respeito, onde mesmo com certa liberdade, muitas coisas participam dessa escolha.

Estando na terceira série do Ensino Médio, a pergunta inicial muda de tempo futuro para um tempo mais próximo, isto é, "quando terminar o segundo grau, o que pretende fazer? O que pretende 'ser' (estar)?" Muitos ficam perdidos, confusos ao responder. São escolhas que refletirão no futuro. Para os que optam por continuar com os estudos, novamente precisam escolher, agora dessa vez, entre o sortimento de cursos: técnicos, profissionalizantes, universitários (QUEIROZ, 2016). Dessa vez, muda-se a pergunta, para: "qual carreira profissional deseja seguir?" Portanto, prosseguem com estudos e mais estudos, a fim de prestar vestibulares, concursos, seleções e, principalmente, o alvo de muitos, fazer o Enxame Nacional do Ensino Médio (ENEM) ${ }^{4}$. Nesse sentido, a decisão para alguns, não é linear, tornando-se uma escolha difícil, adiando-a por mais um tempo, ou seja, são muitas possibilidades que os veem a mente, que os levam a pensar, subjetivados a desejar. Porém, há aqueles que possuem uma escolha determinada, quero "ser" (estar) isso e, ponto. Conhecem os seus desejos.

\footnotetext{
${ }^{3}$ Conceito que será explicado no decorrer do trabalho.

${ }^{4}$ Foi criado pelo Ministério da Educação (MEC), em que consiste em uma prova avaliativa, tanto da qualidade do Ensino Médio (EM) de todo país, como um possível caminho para entrar em alguma faculdade, curso técnico. Assim, o ENEM é considerado como sendo a maior avaliação realizada por estudantes de todo país, sejam eles de Unidades de Ensino público ou privado, independente da faixa etária e/ou em qual ano concluiu o EM.
} 
E se, a escolha de um sujeito seja "ser" professor? Além disso, de Matemática? Visto que, no Brasil, segundo a Folha de Boa Vista (2018), em uma pesquisa realizada pela Organização para a Cooperação e Desenvolvimento Econômico (OCDE) apresenta que os alunos de faixa etária aproximadamente de 15 anos não querem "ser" professores, apontando que apenas 2,4\% desses jovens desejam atuar na docência.

Diante disso, estar professor é uma profissão com grandes desafios, por haver inúmeras dificuldades que tentam obstaculizar a nossa trajetória, como: o desinteresse dos alunos; falta de envolvimento da família com a comunidade escolar; recursos didáticos insuficientes; excesso de trabalho; salários precários; falta de valorização profissional; entre outros. Com isso, o que leva um sujeito a desejar estar professor, em particular de Matemática?

De acordo com Costa (2017), temos que a disciplina de matemática mesmo diante de discussões e contribuições de pesquisadores e interessados visando o desenvolvimento do seu ensino em sala de aula, os resultados do processo de aprendizagem dos alunos deixa a desejar, carregando consigo uma ordem de dificuldade e restrição, ou seja, de que ela é disciplina para poucos, sendo classificada como grande vilã pelos demais alunos. De outro modo, são vários discursos negativos que atravessam essa área de conhecimento, a matemática, desde a parte histórica de que a mesma é para poucos, até o declamar que a mesma é "chata", "difícil", "complexa".

A luz de tudo que foi dito, este artigo engendrado com a Filosofia da Diferença, propriamente, com obras desenvolvidas a partir dos pressupostos teóricos dos filósofos franceses, Michel Foucault (1999), Gilles Deleuze (1994) e Suely Rolnik (1996), intencionou descrever os possíveis processos de subjetivações e/ou agenciamentos transpassaram o devir docente de 22 discentes do curso de Matemática-Licenciatura, da Universidade Federal de Pernambuco - UFPE, Campus Caruaru. Além disso, o estudo percebeu as subjetivações que os levaram a desejar estar docente de matemática, Verificando se houve alguma alteração nas visões dos discentes a respeito do "ser professor" de matemática, após ingressar na universidade, na qual apresentou onde os referidos discentes imaginam-se lecionando daqui a 05 anos.

Diante disso, a pergunta norteadora desse trabalho é a seguinte: Quais possíveis processos de subjetivações e/ ou agenciamentos perpassaram o devir docentes de um grupo de licenciandos do curso de Matemática-Licenciatura? Ressaltamos que, esse trabalho apresenta resultados do recorte de uma pesquisa mais extensa, que foi realizada em consonância com o Núcleo de Formação Docente - NFD, do curso de Matemática-Licenciatura da UFPE - CA. 


\section{Conduzindo-se pelo plano de imanência da Diferença e por alguns conceitos que a ele pertence}

O plano de imanência é onde os filósofos constituem os seus pontos de vista, perspectivas, criam conceitos, mediante os problemas que a atividade filosófica coloca em xeque para serem pensados (GALLO, 2000). Esse autor diz que, o plano de Imanência é a instauração da filosofia, seria o solo fértil, onde os conceitos se interagem e possuem uma existência autônoma, pois o plano é o solo da produção conceitual (horizonte dos acontecimentos), que delimita 0 trabalho filosófico.

Posto isto, dizemos que no plano de imanência, as únicas regiões seriam os conceitos, o qual eles afetam e são afetados entre si, sem partilhar e estritamente relativos (SCHOPKE, 2009). Além disso, os significantes dos conceitos variam conforme o plano de imanência que eles se encontram inseridos e, os movimentos que fazem com que recebam uma nova singularidade. Em outras palavras, os conceitos surgem de outros já existentes. Pois, mediante o plano de imanência que o conceito se encontra vai sendo ressignificado.

Diante do exposto, no plano de imanência da Filosofia da Diferença os conceitos são ressignificados, isto é, são atribuídos outros significantes aos conceitos, na qual, o primeiro que destacamos é a conceituação do conceito diferença, "[...] em que o infinito é o limite da nossa conceituação, pois, o que se tem agora é o conceito da reflexão criativa, que cria o mundo". (HEINEN, V.; HEINEN, L., 2013, p. 242).

Sendo assim, o conceito diferença, não foi criado por Deleuze (LEMOS, 2011), porém, estudos deste filósofo francês são voltados para tal conceito, ou seja, a diferença passa ponderar a quebra do uno, do universal, remetendo a filosofia da multiplicidade, que furta qualquer regra preestabelecida ou modelos, melhor dizer, faz um desfazimento desses paradigmas, pois apesar do plano de imanência da Filosofia da Diferença ser delimitado por conceitos, o conceito de "diferença" reuniu registro interno, singularidade, e o mutável, multiplicidade, de cada sujeito que compõem a sociedade.

De outro modo, na filosofia da diferença, somos compreendidos como sujeitos múltiplos e singulares ao mesmo tempo. Múltiplos por oscilarmos em frequência, "[...] podemos mudar a cada estalar de dedo, um acontecimento, um cheiro, uma fala, enfim uma diversidade de fatores pode altera o que somos." (QUEIROZ, 2016, p. 1). O que estamos sendo, hodiernamente. E, singulares por sermos únicos, ímpares, conseguintemente, cada sujeito possui a sua subjetividade.

Nesse sentido, a subjetividade é a parte secreta de cada sujeito, que está ligada com a multiplicidade, já que a mesma é uma condição provisória do nosso 
devir sujeito, que pode ser transformada ou não, por meio das linhas de forças que estão em circulação na parte exterior a ele $e$, na possibilidade de experimentar e inventar diferentes maneiras de perceber e de agir no mundo. $\mathrm{E}$ essa ação das forças pode perpassá-lo ou não, pois "[...] As existimos e produzimos subjetividades em meio a uma luta." E essa luta ocorre na medida em que acontecem mudanças na população (MANSANO, 2009, p. 112). Dessa forma, a subjetividade não é estática e não funciona apenas no registro de ideologias, mas em nosso coração, na maneira de percebermos o mundo (GUATARRI; ROLNIK, 1996, p. 26), "[...] é algo que pode conduzir à afirmação de valores num registro particular, independente das escalas de valor que nos cercam e espreitam por todos os lados." (GUATARRI; ROLNIK, 1996, p. 47).

Com isso, na medida em que vamos experimentando os momentos, os encontros, que vamos existindo, vão se formando marcas em nosso corpo. Como coaduna Rolnik (1993), elas são os estados inéditos que são produzidos em nossos corpos, a partir das composições que vamos vivendo, são o que ficam depois de uma experiência, depois de encontros, na qual sempre continuam vivas em nossa subjetividade. Encontro refere-se à experiência dupla, em que, afetamos e somos afetados, quer dizer, num encontro existem vários acontecimentos, podendo ter no mínimo dois ou mais sujeitos.

Por sua vez, "A experiência é o que nos passa, o que nos acontece, o que nos toca [...] a experiência é cada vez mais rara." (LARROSA, 2002, p. 21), e, a quem confunda com excesso de informação. Pronto, informação são as coisas que vêm e vão efemeramente, "[...] ela é quase o contrário da experiência, quase uma antiexperiência [...]" (p. 21). Isso é visível nas mídias sociais, onde temos uma abundância de informações, que são ligeiramente substituídas por outras.

Sendo assim, o sujeito constitui a sua subjetividade em meio aos jogos de verdade $^{5}$, relações de poder e de saber. Esses jogos de verdades referem-se a um conjunto de ideias pela qual as verdades são instituídas e desinstituídas em meio aos encontros com o outro social (não-eu) e linhas de forças ${ }^{6}$ que estão num emaranhado dentro da sociedade (MURAD, 2010), nos dispositivos ${ }^{7}$ que adentramos, essas verdades vão resumir o que estamos sendo em um dado momento e quando elas mudam, também mudamos.

De acordo com Brígido (2013) os jogos de verdades são fundamentados em formas de discursos científicos, os quais são reproduzidos por instituições (BRÍGIDO, 2013), sejam religiosas, de ensino, sociais, entre outras, em que ganham valores, que podem perpassar por todo o mundo. Corroborando com

\footnotetext{
6 "Essa linhas estão presentes em todo corpo social estabelecendo uma certa experiência e rompendo com outras." (SALLES, 2016, p. 7). Conceito que explicaremos no decurso do texto.

7 "O dispositivo é um conjunto de linhas que compõem uma rede; linhas múltiplas e de naturezas diferenciadas." (SALLES, 2016, p. 7). É um conceito que será mais explicado no decorrer dessa penumbra.
} 
essas informações, Catto (2010, p. 70) diz que "Em suma, podemos dizer que a verdade está diretamente ligada ao sistema de poder, sustentando-o. Este sistema a elabora e reproduz de acordo com suas necessidades.".

Diante disso, o poder que em todo caso referimos é conceituado por Foucault, na qual o mesmo está descrito no livro, "vigiar e punir" (2014), na qual, a resistência é uma condição necessária para que haja relação de poder, em que, essa resistência não é externa ao poder, ao contrário, é compreendido como uma luta, nem sempre por meio de palavras, mas o fato de ficar em silêncio é uma forma de resistir.

Nesse sentido, a resistência que as relações instituem, está relacionada, do mesmo modo que os discursos, com os jogos de verdades e pode ser considerada como uma possibilidade de linha de fuga (ruptura, fratura), visto como um impedimento ao poder, que permitem novas formas de produção de sujeitos, sendo assim, as relações de poder se diferencia de assujeitamentos, em que o poder não é uma coisa que uns tem e, outros não, ou seja, não está fixo em algo, não é localizável. Alguém só pode tomar algo daquele que tem. Com isso, as relações de poder são produzidas e é fruto da diferença (MARCELLO, 2004), sendo que esse poder não está nos sujeitos, mas age sobre e/ ou conforme eles, melhor dizer, o poder está dentro das relações entre os sujeitos. Como menciona Sousa e Menezes (2020) o poder é algo que funciona nas relações de forças.

O conceito saber no solo da Filosofia da Diferença, é algo que não surge do nada, possui uma raiz, uma origem e uma criação (BRíGIDO, 2013), o qual é possui duas vertentes, a vertente da enunciação, que é formada pelos discursos ${ }^{8}$, por aquilo que espera que o sujeito reproduza e, a vertente da visibilidade, aquilo que espera que o sujeito veja, mas "[...] não se referem à maneira, ao modo específico de ver um sujeito - ou forma que ele concluiu, individualmente, uma determinada coisa [...]" (MARCELLO, 2004). O saber também é relativo, por ser histórico, que possibilita-nos a enxergar o saber que liderava no passado, assim como as linhas de forças que 0 atravessava, para entendermos o presente inacabado (FOUCAULT, 2008) e, dar-nos uma vista para vermos o saber que talvez se constitua no futuro utópico.

Por tudo que foi dito, nunca estamos completos, sempre estaremos à mercê de constituições, pois até as nossas verdades não são fixas, podemos ir mudando na medida em que nos envolvemos com o outro, o não-eu, com as relações de poder e saber. Nesses movimentos é que vamos constituindo as

\footnotetext{
${ }^{8}$ Segundo Fisher (2001), para analisarmos os discursos nas obras de Michel Foucault é preciso desprender das explicações unívocas, fácies interpretações e em conjunto a busca insistente do sentido último e oculto das coisas e, investigar as relações históricas, práticas concretas que estão "vivas" e as enunciações, que são elementos que colocam os discursos em funcionamento. De acordo com costa (2017) os discursos podem ser compreendidos como qualquer forma de comunicação, seja essa, pronunciada ou escrita, podendo ser de maneira direta ou indireta. 
faces provisórias do nosso devir, que descreve o que vamos nos tornando enquanto sujeito, professor, discente.

Conforme Rolnik (1993) o devir é sempre uma diferença, um devir-outro, ou seja, a diferença do nosso agora, com o que éramos. Todavia, o devir está sempre em termos do presente, isto é, não existe passado e nem futuro, pois o ato de olharmos para o que já vivemos é um processo de involução, assim não ficamos presos ao passado, como também ao futuro (DELEUZE, PARNET, 1998).

Diante desse cenário, temos que o devir está sempre entre (meio), entre palavras, entre pensamentos, entre acontecimentos, entre ao não-eu [...] ]entre os encontros (TÁRTARO, 2015). Sobre tais fatores, Deleuze e Parnet (1998, p. 24) apontam que, "O que conta em um caminho, o que conta em uma linha é sempre o meio e não o início nem o fim. Sempre está no meio do caminho, no meio de alguma coisa." Assim, o caminho não possui começo e nem fim e esse meio difere de centrismo, média.

Nessa perspectiva, o devir é constituído mediante aos nossos desejos, que é desordenado, dessa forma, no intervalo, as possibilidades são tomadas na medida em que vamos desejando, somos subjetivados. Sendo assim, o devir de um desejo, sempre começa no meio, não sabemos o dia e nem a hora que fomos despertados por ele, que fomos subjetivados a desejar. "Devir são processos de desejo." (CORAZZA, 2008, p. 92).

Com isso, o curso de Matemática-Licenciatura é uma parte de esse contínuo devir, onde os alunos tornam-se sujeito-licenciando e também, caminham em busca do diploma que certifique que os mesmos possuem um título de graduado em matemática, ou seja, o mencionado curso faz parte da constituição do devir professor desses sujeitos, pois "[...] acontecimento também constitui em um espaço devir." (TÁRTARO; CAVAMURA; SOUZA, 2014, p.4).

Em continuação, "Os modos de subjetivação podem tomar as mais diferentes configurações, sendo que estas cooperam para produzir formas de vida e formas de organização social distinta e, cabe insistir, mutantes." (MANSANO, 2009, p. 114). Não há constituição de um sujeito moral sem processos de subjetivação, em que "[...] é o processo de diferenciação, autoafetação e relações de forças que está por trás da identidade [alteridade] e da estabilidade da subjetividade." (LEMOS, 2011, p.2, grifo nosso).

A subjetividade é uma produção que ocorre em meio aos processos de subjetivações, é o resultado destes processos. A subjetivação, o saber e o poder são elementos que fazem parte da constituição do sujeito, que estão interligados entre si, pois se muda o saber e o poder, muda também a subjetivação. Conforme Levy, "Deleuze vê em Foucault três dimensões fundamentais: a do Saber, a do Poder e a da Subjetivação." (2007, p.1). Diante disso, mediante a esses elementos vamos a nossa subjetividade vai constituindo, o nosso devir vai 
ganhando novas faces provisórias. Essas constituições ocorrem em meio às relações de poder, saber e subjetivação, que são elementos interligados entre si, na qual modificando o saber e o poder, é alterada também a subjetivação. Conforme Levy (2007) "Deleuze vê em Foucault três dimensões fundamentais: a do Saber, a do Poder e a da Subjetivação." (2007, p.1).

Ainda sobre as subjetivações, segundo Queiroz elas são divididas em quatro processos, sendo eles:

Primeiro: quando o sujeito é subjetivado sem seu consentimento, sem que saiba que o está sendo. Segundo: quando o sujeito consente, por não conseguir lutar contra (dobrar a força). Terceiro: quando o sujeito consente com o processo de subjetivação. Quarto: quando nem consente e nem se deixa subjetivar. (2015, p.5).

Com isso, a subjetivação é sempre uma ação, é o que nos faz desejar, a querer algo material ou imaterial, assim, o desejo nasce na parte externa do sujeito. Isso implica que somos "[...] movidos pelo desejo [...]" (ROLNIK, 2003, p.7), sejam eles dirigidos unicamente a nós e/ou em satisfazer o outro (QUEIROZ, 2016). Portanto, "O desejo não é um sentimento, ele é afeto, distanciando-se do substantivo afeição, aproximando-se do verbo afetar. Desejamos aquilo que nos afeta, nos agencia ${ }^{9}$." (QUEIROZ, 2016, p.2).

Em harmonia com Guattari e Rolnik (1996) trazemos que no desejo não há universais e pode ser visto como um caos, componente da subjetividade, pois este pode ser denominado como todas as formas de vontade de viver; de criar; amar e de inventar outra sociedade, assim, o desejo pode ser algo revolucionário. E o desejo sempre constrói algo e se apresenta por meio de diferentes afetos. E entende-se que escolher uma carreira profissional está atrelado ao desejo de mudança social, econômico e cultural. Nessa acepção, o desejo é transformador, é revolucionário, é propulsor, é ele que movimenta o sujeito a caminhar, a trilhar pelos seus sonhos, ou seja, os sujeitos são movimentados pelos seus desejos.

Em conformidade com a transcrição integral do vídeo "O abecedário de Gilles Deleuze"10, para Deleuze, desejamos em um conjunto, em que, desejar é construir um agenciamento, um conjunto, como discorre a seguir:

Nunca desejo algo sozinho, desejo bem mais, também não desejo um conjunto, desejo em um conjunto. Podemos voltar, são fatos, ao que dizíamos há pouco sobre o álcool, beber.

\footnotetext{
${ }^{9}$ Conceito que será trazido mais adiante.

${ }^{10} \mathrm{http} / / /$ stoa.usp.br/prodsubjeduc/files/262/1015/Abecedario+G.+Deleuze.pdf. Acessado em: 15 maio 2019.
} 
Beber nunca quis dizer: desejo beber e pronto. Quer dizer: ou desejo beber sozinho, trabalhando, ou beber sozinho, repousando, ou ir encontrar os amigos para beber, ir a um certo bar. Não há desejo que não corra para um agenciamento. $O$ desejo sempre foi, para mim, se procuro o termo abstrato que corresponde a desejo, diria: é construtivismo. Desejar é construir um agenciamento, construir um conjunto, conjunto de uma saia, de um raio de sol... (DELEUZE, p.14).

Além disso, as possibilidades do desejo são os agenciamentos (composições de desejos). O “desejo jamais é uma determinação 'natural', nem espontânea [...] o desejo circula [nos] agenciamento de heterogêneos, nessa espécie de 'simbiose': o desejo une-se a um agenciamento determinado; há um co-funcionamento." (DELEUZE, 1994, p.3, grifos nossos). E, de acordo com Deleuze (1994) o "[...] desejo não comporta qualquer falta. Ele não é um dado natural. Está constantemente unido a um agenciamento que funciona." (p. 6). Desse modo, o mesmo conceitua o desejo como sendo um processo e, ao invés de sentimento, ele é um afeto (afetação). Ao contrário de objeto ou pessoa, ele é acontecimento.

Assim, o agenciamento são convites lançados aos nossos desejos. Sendo que, esses convites não são literais, pois não vem do nada, na qual, os mesmos nos atraem, fazendo-nos, vibrar. Com isso, o desejo está ligado ao agenciamento, no entanto, para que ocorra um agenciamento é necessário que o sujeito seja subjetivado, nesse contexto, subjetivado a desejar. Essa conexão acontece, porque os desejos são constituídos fora de nós, no exterior dos sujeitos, que é a composição dos encontros, acontecimentos, subjetivações e agenciamentos que os envolvem, dos dispositivos que os capturam a habitar em detrimento de outros.

Assim, adentramos em alguns dispositivos em detrimentos de outros, existimos em vários, subjetivando e sendo subjetivado, na qual, os dispositivos que permanecemos, serão os nossos territórios existenciais, em que, o desejo é o processo de construção desses territórios existenciais. Todavia, como trazido, o vetor desejo é constante, muda de direção, ao mudarmos de dispositivos (QUEIROZ, 2015) ou não, pois às vezes, continuamos em alguns, mesmo não aceitando os discursos que são propagados por eles, pois o desejo nem sempre está no dispositivo, mas no que iremos conseguir por meio dele, pois, é dos dispositivos que vem os convites concretos ao nosso desejo. Como trazido, resistir nem sempre é escapar das linhas de forças.

Assim, os dispositivos tentam nos transformar em sujeitos homogêneos para poder exercer seu controle sobre nós. Quando mencionamos homogêneos, estamos dizendo que não aceita "diferentes", é como uma máquina de fabricar sujeitos iguais. Os dispositivos podem ser físicos e/ou não físicos. Conforme Salles: 
O dispositivo é um conjunto de linhas que compõem uma rede; linhas múltiplas e de naturezas diferenciadas. Não linhas que demarcam um território ou delimitam uma experiência, constituindo uma espécie de sistema homogêneo. Trata-se antes de linhas móveis que pelos seus traçados múltiplos e variáveis configuram um espaço e uma experiência. Sendo assim, a multiplicidade não diz respeito a vários sistemas que se entrecruzam, mas linhas que atravessam as experiências provocando desequilíbrio na medida em que se aproximam ou se afastam umas das outras. Portanto, o dispositivo é uma complexidade de linhas que estão sempre seguindo diferentes direções e sofrendo variações. (2016, p.7).

Desse modo, segundo Deleuze (1990) dispositivo "[...] é uma espécie de novelo ou meada, um conjunto multilinear." (p. 155), que possui diferentes linhas de forças, que tanto se aproximam, como se afastam uma das outras, por direções diferentes, quer dizer, o dispositivo é heterogêneo, na qual, essas linhas de forças se encontram num emaranhado, em que nesse meio, podemos destacar as linhas que compõe todos os dispositivos, que são: as linhas do saber (enunciação e visibilidade), do poder e de subjetivação, essas linhas não operam fora dos dispositivos. Essas linhas não possuem um modo definitivo, pois se transformam para não nos deixarem escapar, pois a principal função de um dispositivo é manter o controle (capturar, orientar, determinar, interceptar, modelar).

Linhas são forças que penetram os corpos sociais, em busca de estabelecerem discursos. Reavendo o poder disciplinar descrito por Foucault (2014), fica nítido o que queremos dizer, pois visava sempre o controle, por meio dos dispositivos disciplinares, em que sempre criava novas formas de punições e de vigilâncias, na medida em que observavam que os sujeitos estavam tentando desviar dos processos de assujeitamentos. Assim, os dispositivos são uma realidade móvel (SALLES, 2016).

As linhas de enunciação distribuem as posições diferenciais dos elementos, tais como: discursos, organizações arquitetônicas, instituições, leis, enunciados científicos [...] proposições filosóficas, que compõem os dispositivos e, a visibilidade modifica esses elementos (DELEUZE, 1990). Esses elementos estão numa espécie de rede, que só apresentam aquilo que quer que nós vejamos, o dito e não dito, que são as linhas de forças que compõe o poder, na qual permeiam todas as demais, em que não estão no enunciável e no visível, mas também no invisível e indizível (QUEIROZ, 2015).

Desse modo, precisamos transcender a enunciação e a visibilidade e olhar por traz de cada dispositivo, mas, para tanto, precisamos conhecer os nossos desejos e as linhas de forças que os atravessam, através de mapeamentos, tracejados, cartografias. Sendo assim, a dimensão da linha de subjetividade, que escapa todas as anteriores, pode ser considerada como uma linha de fuga (fratura), uma dobra, na medida em que se mudam os processos 
de subjetivação, modificamos aquilo que acreditávamos, a querer seguir por outro modo de vida, reproduzindo novos discursos, e talvez sejamos produtores de novos dispositivos. "Essas linhas estão presentes em todo corpo social estabelecendo uma certa experiência e rompendo com outras." (SALLES, 2016, p. 7).

Assim, a subjetivação, que advém da correspondência entre o saber e o poder, é uma produção de subjetividade, é o que nos faz adentrar em alguns dispositivos, em lugar de outros, ou seja, escapamos dos poderes e saberes de alguns dispositivos, para sermos conduzidos, por outros poderes e saberes de outro (DELEUZE, 1990).

\section{Metodologia}

A metodologia utilizada é de abordagem qualitativa, entendida como um campo natural de fonte direta de dados, tendo o pesquisador como instrumento fundamental para reflexão dos significados que as pessoas dão as coisas e à sua vida e, análise da realidade por meio da utilização de métodos e técnicas para a compreensão detalhada do objeto de estudo. Possui um caráter descritivo e um enfoque indutivo. (OLIVEIRA, 2016).

O recurso metodológico para produção de dados foi um questionário (quadro 1), composto por 05 questões (Quadro 1) discursivas e, aplicado a 22 discentes que estão cursando a licenciatura em Matemática (tabela 1), da Universidade Federal de Pernambuco (UFPE), Campus Caruaru. Escolhemos esses alunos, devido à proximidade em finalizar a graduação. A aplicação foi feita com autorização da professora da disciplina eletiva Formação de Professores de Matemática, ofertada no semestre 2018.1, com carga horária total de 60 horas. Os encontros da referida disciplina ocorreram nas terças feiras, no período noturno.

Tabela 1: Quantitativo de alunos por semestres

\begin{tabular}{c|c}
\hline Semestres & Quantitativo de alunos por semestres \\
\hline 2016.2 & 01 \\
\hline 2015.2 & 01 \\
\hline 2014.2 & 01 \\
\hline 2014.1 & 06 \\
\hline 2013.2 & 07 \\
\hline 2013.1 & 04 \\
\hline 2012.2 & 02 \\
\hline 2012.1 & 01 \\
\hline 08 Semestres & 22 Licenciandos \\
\hline
\end{tabular}

Fonte: Acervo da pesquisa (2020). 
Visando respeitar os critérios éticos na nossa pesquisa, que institui total anonimato dos sujeitos pesquisados, ao destacarmos suas respostas em nossa análise, os nomeamos como: S1, S2 ... S22.

Dessa forma, o questionário (quadro 1) foi estruturado e organizado com pretensão de descrevermos, destrinchamos quais processos de subjetivações e/ou agenciamentos estão presentes no devir professor dos discentes do curso de Matemática Licenciatura. Por outra maneira, descrever as subjetivações que os impulsionaram a desejar estar professor, especificamente de matemática. $\mathrm{E}$ onde os mesmos se imaginam lecionando daqui a 05 anos, em outras palavras, dialogar com os objetivos elencados neste trabalho.

\section{Quadro 1: Perguntas presentes no questionário com seus respectivos objetivos}

\begin{tabular}{|l|l|}
\hline \multicolumn{1}{|c|}{ Pergunta } & \multicolumn{1}{c|}{ Objetivo } \\
\hline $\begin{array}{l}\text { 1. Antes de entrar na licenciatura, } \\
\text { o que pensava a respeito da } \\
\text { docência? }\end{array}$ & $\begin{array}{l}\text { Compreender as visões que os licenciandos } \\
\text { tinham acerca da docência, antes de entrar na } \\
\text { universidade. }\end{array}$ \\
\hline $\begin{array}{l}\text { 2. E atualmente, sua visão mudou } \\
\text { ou continua a mesma? Porquê? }\end{array}$ & $\begin{array}{l}\text { Descrever se houve alterações das visões dos } \\
\text { licenciandos a respeito da docência durante o } \\
\text { convívio na graduação. }\end{array}$ \\
\hline $\begin{array}{l}\text { 3. Por que optou por cursar a } \\
\text { Licenciatura em Matemática? }\end{array}$ & $\begin{array}{l}\text { Descrever os processos de } \\
\text { subjetivações/agenciamento que levaram os } \\
\text { alunos a escolher o curso. }\end{array}$ \\
\hline $\begin{array}{l}\text { 4. O que você mais admira em } \\
\text { um/uma docente de matemática? }\end{array}$ & $\begin{array}{l}\text { Descrever o que os licenciandos mais admiram } \\
\text { em um/uma docente de matemática. }\end{array}$ \\
\hline $\begin{array}{l}\text { 5. Como e onde você se imagina } \\
\text { lecionando Matemática daqui } \\
\text { cinco anos? }\end{array}$ & $\begin{array}{l}\text { Perceber se os discentes desejam estar } \\
\text { professor daqui a cinco anos. Caso sim, } \\
\text { descrever onde os mesmos imaginam-se } \\
\text { lecionando, por conseguinte, quais professores } \\
\text { desejam se tornar. }\end{array}$ \\
\hline
\end{tabular}

Fonte: Acervo da pesquisa (2020).

\section{Resultados e Discussões}

Neste tópico, organizamos as respostas dos 22 (vinte e dois) discentes pesquisados em categorias de acordo com as convergências (pontos em comum), visando responder a questão norteadora do nosso estudo, a saber: Quais possíveis processos de subjetivações e/ou agenciamentos perpassaram o devir docentes de um grupo de licenciandos do curso de Matemática- 
Licenciatura? Nesse sentido, acentua-se que, as categorizações (mesmo que seja algo que vai de contra a teoria que utilizamos) foram à forma que encontramos para destrinchar as respostas, já que esta não se trata de uma pesquisa cartográfica.

No entanto, mesmo diante das categorizações, consideramos as respostas como sendo impares, únicas, em que, para tal organização, atamos os indícios comuns entre elas. Contudo, não seguimos necessariamente a ordem apresentada pelas perguntas do questionário. Então, iniciamos pela terceira, entrelaçando-as num diálogo, os quais se complementam entre si, apresentando recortes do devir professor de cada sujeito que compõe essa pesquisa.

A terceira pergunta, "Por que optou por cursar a Licenciatura em Matemática?" (quadro 1), permitiu-nos perceber as subjetivações que permearam a escolha dos discentes pela área da docência, especificamente da matemática. Como trazido nos pressupostos teóricos deste trabalho, as subjetivações é o que nos fazem desejar, é o que atravessam o nosso devir, as nossas escolhas, que dependem dos encontros e desencontros que participamos nos dispositivos que adentramos. Às vezes, mudamos os nossos desejos para rotas diferentes, por não termos suporte de segui-los, no caminho que tínhamos arquitetado. Existem acasos, idas e vindas. Desterritorialização e reterritorialização ${ }^{11}$. O desconhecido, obscuro, o inédito. Os convites.

Com isso, dentre as respostas a essa pergunta, encontramos que alguns optaram cursar matemática licenciatura por falta de opção, baixa concorrência, por ser entre as opções de curso ofertadas na região dos discentes, a que mais se identificaram. Entre os discentes, encontramos os que desejavam cursar alguma área da engenharia. Porém, as subjetivações mudaram os seus desejos de direção. Como ilustram as seguintes respostas:

S2. De início, pensava em cursar o curso de licenciatura, só para poder entrar na universidade e com um tempo poder migrar para o curso de engenharia [...].

S5. Na época em que escolhi cursar foi a opção que mais identifiquei (sempre gostei de matemática). Antes, tenha tentado engenharia civil e não consegui.

S8. Por gostar de números e também como forma de construir uma base para o curso de engenharia, que era o sonho de infância, mas deu lugar a uma realidade.

\footnotetext{
${ }^{11}$ Conceitos criados pelos filósofos franceses Gilles Deleuze e Félix Guattari, em que é Desterritorializar é o ato de sair de um território. E reterritorializar é a chegada em outro território ou retorno ao território que autrora saiu. Os movimentos de ambos podem ser físicos ou não, materiais ou não, pois podemos desterritorializar e reterritorializar com os nossos pensamentos, reflexões, em leituras, escritas, entre outras possibilidades.
} 
S11. No começo gostaria de cursar engenharia civil, mas como era durante o dia e eu precisava trabalhar, ai optei por algo das exatas a noite e por já ter dado algumas aulas de reforço.

S15. Falta de opção. Ou era licenciatura em matemática ou pedagogia.

S22. Por gostar da disciplina e pela baixa concorrência.

A resposta de $\mathrm{S} 11$ acentua que nem todos possuem as mesmas possibilidades, ou seja, a necessidade de trabalhar durante o dia foi o empecilho para cursar engenharia, seu desejo a priori. Os S5 e S8 decidiram cursar o referido curso por pertencer à área de exatas. Os sujeitos S2 e S8 desejavam ingressar no curso para fazer transferência interna e/ou formar uma base para engenharia, ou seja, adentrou no curso não pela docência, mas pelo que poderia conseguir por meio dela.

Além do curso de engenharia, evidenciamos as resposta de S15 e S22 que não tinham o curso de licenciatura como algo que desejavam, fazendo-os optarem pelo curso devido à baixa concorrência. Observando o que S15 disse sobre escolher entre os cursos de Pedagogia e Matemática, mesmo tendo na UFPE outros cursos voltados à docência, expondo com isto uma possível preferência pela Matemática (curso escolhido), por gostar da disciplina durante a Educação Básica, ou não. Como trazido no referencial teórico deste trabalho a Matemática pode ter sido um monstro que o mesmo desejou enfrentar. Dobrar a força.

Com isso, tem-se que eles não foram agenciados pela profissão de professor inicialmente, onde o processo de subjetivação que levou a desejar cursar o mencionado curso foi à área de conhecimento, exatas. Outro sim, mesmo que balizamos as subjetivações de falta de opção, baixa concorrência, que são denotações abrangentes, nota-se, que essas subjetivações atravessaram de maneira diferente cada um dos sujeitos expostos. Como foi o caso de S5 e S11, os seus desejos seguiram por caminhos diferentes, um se frustrou na tentativa de ingressar em outro curso, talvez o medo o impedisse de tentar novamente, e o outro pela necessidade de trabalhar durante o dia. Assim, isso enfatiza que a trajetória dos sujeitos que adentram na UFPE é diferente. $O$ devir é diferente.

O gosto pela matemática foi o fator que subjetivou e agenciou os discentes a optarem pelo curso, atrelado a facilidade e encanto pela mesma. Assim, podemos dizer que possivelmente os professores de Matemática deles no dispositivo-escola, os subjetivaram, ou seja, as aulas ministradas por eles foram um campo recheado de convites, agenciamentos. Assim, esses alunos foram marcados de maneira positiva nos encontros que tiveram com a matemática. Coube a estes professores promover verdadeiros encontros que desmistifica os 
discursos negativos em relação à matemática. As respostas de $\$ 16$ e S21 ilustram isto, são elas:

S16. Porque sempre gostei da disciplina de matemática e tive ótimos professores que me serviram de exemplo.

S21. Por gostar da disciplina e dos professores que fazem acreditar na docência.

De acordo com essas respostas, nota-se, que mesmo diante das dificuldades que atravessam a profissão de professor, existem alguns que subjetivam os alunos a acreditar e desejarem a docência, em que, percebe-se, que na realidade da Educação, muitos professores estão adoecidos, sufocados pelas dificuldades, por falta de interesse dos alunos. Disto nos vem o questionamento: Como despertar o desejo dos alunos para seguir uma carreira que explicita tanto descontentamento? Atuar na docência é um desafio, um caos, onde poucos vestem a camisa e propõem convites por intermédio de suas aulas, como foi evidenciado nas respostas $\$ 16$ e $\$ 21$. Entretanto, reconhecemos que as dificuldades nos sufocam, e ficamos vulneráveis, a ponto de querermos desistir. Assim, estar professor é uma incessante luta. Além disso, percorrendo pelo questionário percebe-se, que além do gosto pela disciplina, muitos discentes foram subjetivados a desejar atuar na docência, desde a infância. Nessa acepção, os processos de subjetivação foram advindos dos professores que os mesmos tiveram no dispositivo-escola, no dispositivo cursinho prévestibular, e de familiares que atuam na área da educação, ou seja, eles foram agenciados. Como mostra os recortes das respostas dos licenciandos em seguida:

S3. Por minha família ser toda na área da educação, e por eu gostar de matemática desde criança e, também, por facilidade de questão de trabalho.

S13. [...] desde criança me sentia atraída pela docência e no decorrer dos anos, com ótimos professores de matemática que tive, passei a gostar muito da disciplina e optei por unir a vontade que tinha de ser professora com algo que eu gostava bastante.

Assim, muitos adentram em alguns dispositivos pelos desejos demasiados da infância, aonde esses desejos fomentam e os conduzem a trilhálos. Conforme foi apresentado neste trabalho, os desejos só ocorrem em agenciamento. Portanto, S3, S13, entre outros, foram convidados a almejarem à docência, através das subjetivações procedentes dos familiares que de certa forma elencaram esses desejos e também pelos professores que tiveram. Fortificando-os, que até este momento, muitos acreditam e lutam pela docência. 
Podemos envolver isso o amor e o compromisso pela profissão que exercem. Porque alguns estão nesta profissão por falta de opção, não por acreditarem em dias melhores na educação do nosso país, com profundidade a educação pública, precisamente do dispositivo-escola.

Seguindo com as descrições dos dados, temos que alguns sujeitos foram despertados, subjetivados a querer seguir a referida profissão, quando ajudavam os seus colegas de classe, tirando dúvidas sobre os conteúdos, guiando-os entre as dificuldades. Como está explicito nas respostas de S1 e S9, são elas:

S1. Sempre gostei de matemática e, também, porque gostava de ajudar meus colegas quando estavam com dificuldades em aprender determinado conteúdo da matemática.

S9. Por gostar da disciplina e ter mais facilidade em aprender e ajudar meus colegas.

Com isso, vários alunos são subjetivados a desejar a docência quando se sentem capazes de ajudar o próximo, quando conseguem acompanhar uma disciplina e acreditam que aprenderam os conteúdos. Têm aqueles que na infância brincavam de escolinha, recebendo a função de professor. Imagina-se, que os seus desejos pela profissão de professor foram despertados no dispositivo-sala de aula.

Alguns alunos foram subjetivados pela facilidade de conseguir emprego, como apresentou a resposta de S3 no decorrer dessa descrição. Além dessa resposta encontramos as de:

S6. Pela facilidade do mercado de trabalho e por gostar de matemática.

S20. Por ser uma área boa para conseguir emprego.

Dessas duas respostas, principalmente a de S20, imagina-se, que os mesmos ingressaram no curso não pela docência em si, mas pelo que iriam conseguir por meio dela. E também, a procura por emprego é um coeficiente subjetivador, o qual muda a rota dos desejos de muitos.

Em descrição das respostas da primeira pergunta, "Antes de entrar na licenciatura, o que pensava a respeito da docência. $E$ pela segunda, $E$ atualmente, sua visão mudou ou continua a mesma? Por quê?" (Quadro 1). Faremos a descrição dos dados dessas duas perguntas concomitantemente, pois a segunda é decorrência da primeira, ou seja, uma retorna ao devir dos alunos antes de ingressar na universidade (retorno) e a outra apresenta a face provisória do devir presente (na atualidade). 
A primeira pergunta nos permite descrever as visões dos licenciandos a respeito da docência antes de entrar na universidade, além de permitir perceber os reflexos de subjetivações que levaram os discentes adentrarem na graduação, em outras palavras, os reflexos das respostas a pergunta que foi descrita anteriormente. A segunda pergunta permite perceber se as visões dos discentes em relação à docência mudaram, ou seja, explanar as subjetivações que os perpassam após adentrar no dispositivo curso de matemática licenciatura.

Com isso, os processos de subjetivações expressados pela falta de opção, baixa concorrência, está atrelado a visões de indícios negativos acerca da docência, em que os alunos, não se sentiam atraídos por ela, por tê-la como algo chato, sendo um trabalho árduo e desvalorizado. Entretanto, na medida em que os sujeitos refletem as dificuldades acerca de uma profissão, constituem-se os seus pensamentos em relação a ela. São vários discursos procedentes da sociedade, que denotam as dificuldades que perpassa a relatada profissão, onde são constantemente divulgados nas mídias sociais. Também, é visto quando os professores organizam protestos, em prol de melhorar as condições de trabalho. As dificuldades que perpassa à docência são visíveis a todos. Como trazido nas respostas de S2, S11 e S15, alunos que não desejavam "ser docente".

S2. Que não queria cursar uma licenciatura, pois sempre pensei negativamente, como uma profissão que não é valorizada, financeiramente e profissionalmente.

S11. Algo chato, complicado e desvalorizado.

S15. Sempre vi a docência independente da área, como um trabalho árduo, com pouca valorização, porém de suma importância para a vida acadêmica de qualquer indivíduo.

Essas respostas exprimem o peso dos discursos negativos que a profissão de professor acarreta, onde adentrar na docência para muitos não é um desejo inicial. Reforçam que a desvalorização profissional e financeira são as linhas de forças que subjetivam a população a não desejar à docência. No entanto, mesmo diante desses pontos negativos, S15, reconhecia a importância da mesma na vida acadêmica dos discentes. Todavia, após o seu ingresso no apresentado curso, a sua visão continua a mesma, sem expressar justificativa.

Perpassando pelas respostas de S2 e S11, nota-se que, os seus pensamentos mudaram, no decorrer da prática na sala de aula, apesar de admitir as dificuldades, como mostram as suas respostas.

S2. Em partes continua a mesma, no sentido que não é valorizada financeiramente e profissionalmente. Mas se partir para a profissão, hoje sou apaixonada pela docência. Gosto de 
contribuir na aprendizagem dos alunos.

S11. Sim, pelo convívio com algumas situações vividas em meio acadêmica e, também, profissional.

Ainda dentre os indícios negativos possuem aqueles sujeitos que não foram agenciados a atuarem na docência durante a sua vida escolar, no entanto, foram agenciados por outras instituições de ensino, que os conduziram ao curso de Matemática-Licenciatura. Dessa forma, frisamos a resposta de S19 da primeira pergunta: "Eu nunca pensei que estudaria para ser professor, tive professores que de certa forma não incentivavam os alunos a estudarem de fato, como deve, e foi no cursinho que teve professores ótimos que me incentivaram a estar aqui hoje.". E também, retomamos a sua resposta atribuída à terceira pergunta: "Como na resposta 1 tive professores no cursinho que me incentivaram a cursar matemática, coisa que antes do cursinho eu odiava matemática.". Trazemos essas duas respostas, por se completarem entre si, tal como o sujeito apresenta.

Com isso, S19 traz que durante o seu devir escolar, não gostava da disciplina de matemática, muito menos da docência, onde faz uma crítica às práticas de ensino dos professores de matemática que teve na Educação Básica, além de ressaltar que de certa forma não o incentivaram a querer "ser professor", nem estudar e nem gostar da disciplina por eles lecionada. Também ele frisa que os professores que ele teve na Educação Básica apresentavam as aulas semelhantes a um sacerdócio. Dessa fala supõe-se que aulas eram monótonas, sólidas, arcaica e que concentrava todos os conhecimentos no professor, ou seja, os professores eram os centros das aulas e não os alunos. À vista disso, o seu desejo pela docência manifestou-se quando estava no cursinho prévestibular, onde o mesmo traz que os professores dessa unidade de ensino, o incentiva por meio das suas aulas a querer trilhar pelo mesmo caminho.

Como mostra a sua resposta a segunda pergunta: "Mudou porque hoje cursando matemática licenciatura posso perceber que a profissão professor não sacerdócio como eu fui levado a acreditar durante minha vida escolar e com uma profissão como outra qualquer que exige formação, especificidades estas vistas durante o curso." No plano de imanência da Filosofia da Diferença, trocamos o verbo "incentivar" para "agenciar". Ele foi agenciado pelos professores do cursinho a gostar de uma disciplina que outrora tinha aversão, a ponto de querer ensiná-la.

Aprendemos de forma diferente, ligado a isto, vêm às metodologias. Dessa forma, dentre os alunos que participavam dos encontros com ele, no dispositivo-escola, algum poderia gostar da forma que os professores abordavam os conteúdos. Os atributos do que seria um "bom professor" são relativos. 
Assim, observa-se que, foi despertado o desejo pela docência em S19, num cursinho, após participar de encontros com a matemática diferente dos que ele tinha no dispositivo-escola. Já S2 e S11 foram subjetivados tanto pelo ambiente acadêmico como pela pratica na sala de aula a olhar à docência de forma diferente, a ponto de apaixonar-se por ela, sendo agenciados. Outra resposta que denota essa conjuntura é a de S8, em que o mesmo não se sentia atraído pela docência antes de ingressar na universidade, mesmo reconhecendo ser uma bela profissão. No entanto, a sua visão foi alterada, durante o contato com as suas primeiras turmas, o qual observou que poderia multiplicar conhecimentos, aprender com os seus alunos, onde hoje não se imagina fazendo outra coisa. Como apresentam as suas respostas da primeira e da segunda questão, respectivamente: "Não era algo que me atraia, apesar de achar uma bela profissão. Eu achava que por causa da minha timidez teria dificuldade para lecionar" e "mudou". Depois dos primeiros contatos com turmas do ensino básico, percebi que tinha a possibilidade de multiplicar conhecimentos e as mesmo tempo aprender com os alunos era muito interessante e também gratificante e hoje não me vejo fazendo outra coisa.".

Alguns discentes antes de ingressar na licenciatura tinham em mente que a docência era uma profissão maravilhosa, bela. Um campo de crescimento e experiência continua. Com isso, eles atribuem à profissão pontos positivos, que nos permitem encontrar alguns vestígios das subjetivações apresentadas pela terceira pergunta, por exemplo, os que desejavam à docência desde a infância. Como mostra a resposta de S13: "Sempre admirei a profissão, pois tenho várias tias professoras, por isso desde criança eu me sentia atraída pela docência.". Então, a mesma foi subjetivada a desejar à docência por meio do convívio com as suas tias, ou seja, ela foi agenciada. Durante a graduação a sua visão continuou a mesma, "mas a admiração aumentou, pois trabalhando em sala de aula vemos as dificuldades que os professores enfrentam em seu dia a dia e mesmo assim continuam na "luta" pela educação". Com isso, é perceptível que muitos apesar das dificuldades insistem na luta, perseveram, gostam do que fazem. Assim, ela demonstra se sentir realizada na profissão que segue. Além dessa resposta que apresenta indícios positivos da mencionada profissão, temos:

S3. Que é uma das profissões mais maravilhosas que existe na face da terra.

S5. Que é a profissão mais importante de todas, pois é nela que as outras profissões são possíveis.

S9. Que seria uma experiência e um crescimento sem comparação na área do ensino de matemática. 
Dessa mescla, apontamos a resposta de S5, pois o mesmo mostrava não querer seguir carreira na docência, dando a entender que foi subjetivado apenas pela disciplina de matemática, o qual se destaca no primeiro diagrama de respostas apresentado no prelúdio deste capítulo. Entretanto, de acordo com essa resposta, ele reconhece que a profissão de professor é a mais importante. Então, de onde surgiu esse pensamento pela docência? Foi antes ou depois de tentar engenharia? Caso tenha sido antes, por que não tentou adentrar na profissão mais importante, proferida por ele? Logo, imagina-se pelas suas declamações que não foi apena o gosto pela disciplina, mais também pela docência. Por isso a importância do entrelaçamento das perguntas, pois se completam entre si, apresentando o que não estava nítido. Trazendo recortes do devir professor dos sujeitos desta pesquisa. Têm os alunos que pensava que "ser professor" era somente ensinar os conteúdos e estudar para dá aula, como foi o caso de S1, S10 e S16, na devida ordem: "Pensava que a missão do professor era ensinar o conteúdo e nada mais, além disso.", "Quem estuda para dá aula", "Tinha uma visão abreviada do que é ser professor, para me, ser professor bastava ter conhecimento do conteúdo.". Dessa forma, as visões desses licenciandos acerca da docência, eram concisas, sucintas, refletindo que durante a sua vida acadêmica apenas tiveram aulas tradicionais, em que os professores apenas ensinavam os conteúdos. No presente, as suas visões foram alteradas, como mostram a seguir:

S1. Mudou, entendo que a missão de professor vai além do conteúdo programado. É necessário o professor se autoavaliar sobre as suas práticas, se estão surtindo efeitos positivos ou negativos; se o aluno está aprendendo ou não; tentar entender as dificuldades dos seus alunos para tentar saná-las.

S10. Mudou, pois a docência tem que ser por amor.

S14. Continua a mesma. A cada sai que passo, porém acho que nós, como futuros professores temos de fazer nossa parte a mais e mais dificuldades.

S16. Atualmente, minha visão mudou totalmente, pois sei que ser professor não é apenas saber a matemática e sim as matemáticas, ser professor é ser pesquisador.

Portanto, o desejo deles continua sendo a docência, entretanto, dispõese que não é apenas saber dos conteúdos, mas saber ensiná-los, visando à aprendizagem dos alunos, e também, que o professor precisa avaliar as suas aulas, com intuito de diagnosticar o desempenho escolar dos alunos. Quando S1 diz que precisa verificar os efeitos suscitados pelos professores nos alunos, nos pressupostos teóricos deste trabalho seria as marcas, que pode ser de Natureza positiva ou negativa. O mesmo apresenta uma preocupação com a aprendizagem dos alunos. Da resposta de S16, traz a necessidade de os professores serem pesquisadores, ou seja, aprofundar os conhecimentos 
matemáticos. E quando o mesmo traz que o professor precisa conhecer "as matemáticas", subtende que seria a matemática formal (apresentada na escola) e a informal (fora dos muros da escola), assim como as diversas metodologias, práticas de ensino.

Atravessando as respostas de $S 14$, repara-se que ele entrou na graduação pela facilidade com a disciplina, em que a docência para ele era uma profissão como outra qualquer, cheia de obstáculos e dificuldades. Atualmente, a sua visão continua a mesma, em que não se imagina lecionando. Assim, supõe-se, que o mesmo possui outras finalidades com seu diploma ou simplesmente desejou apenas cursar o referido curso.

Dentre os que ingressaram visando à facilidade de conseguir emprego, destacamos a resposta de S20: "Achava que seria uma área boa para emprego. Nunca pensei na docência em si, em como ver um professor, compartilha saberes, fui mais pela área educacional." Como mostra o mesmo não pensou na docência em si, o seu alvo, igualmente a muitos, foi o que poderia conseguir por meio dela, ou seja, pensou na facilidade de conseguir um emprego. Além disso, foi pela a área de conhecimento, nesse caso, matemática. $\mathrm{Na}$ atualidade, sem dialogar a respeito, a sua visão mudou um pouco, porém, está cursando licenciatura como segunda opção, para não ficar desempregado. Essa conjuntura é visível em muitos que atuam na docência. Muitos não estão pelo desejo de contribuir com a aprendizagem dos alunos, não tem o desejo demasiado de mudança ou de atuar nesse oficio. Talvez tenham desejo de seguir outra profissão, mas permanecem, (re) produzindo marcas negativas e fortificando o mar de desinteresse.

Tabela 2. Relação (mudança) da visão dos licenciandos antes e durante $o$ curso

\begin{tabular}{|c|c|c|c|c|}
\hline \multirow[t]{2}{*}{$\begin{array}{l}\text { Categorias } \\
\text { (atributos por } \\
\text { proximidades) }\end{array}$} & \multicolumn{2}{|c|}{$\begin{array}{c}\text { Visões dos } \\
\text { discentes antes de } \\
\text { ingressar na universidade } \\
\text { a respeito da docência ( } 1^{\circ} \\
\text { pergunta) }\end{array}$} & \multicolumn{2}{|c|}{$\begin{array}{c}\text { Mudanças das visões a } \\
\text { respeito da docência ( } 2^{\circ} \\
\text { pergunta) }\end{array}$} \\
\hline & $\mathrm{N}^{\circ}$ & $\%$ & $\mathrm{~N}^{\circ}$ & $\%$ \\
\hline $\begin{array}{l}\text { Indícios negativos ( } \\
- \text { ) }\end{array}$ & 07 & $31 \%$ & 05 & $22,7 \%$ \\
\hline Indícios positivos (+) & 05 & $22,7 \%$ & 02 & $9,1 \%$ \\
\hline Em partes (+/-) & 07 & $31 \%$ & 02 & $9,1 \%$ \\
\hline $\begin{array}{l}\text { Apenas ensinar o } \\
\text { conteúdo }\end{array}$ & 03 & $\%^{13,5}$ & 03 & $13,5 \%$ \\
\hline Total & 22 & $100 \%$ & 12 & $54,5 \%$ \\
\hline
\end{tabular}

Fonte: Dados da pesquisa. 
De modo geral, conforme a tabela 2, 31\% dos alunos não desejavam a princípio cursar licenciatura, apresentando apenas indícios negativos, em relação à docência. Após o ingresso, 18, 1\% desses, mudou os seus pensamentos, em que não se imaginam fazendo outra coisa, se encantaram, se apaixonaram por ela, mesmo reconhecendo as dificuldades, obstáculos. Assim, percebe-se, que esses alunos foram subjetivados/agenciados pela docência no dispositivo curso de Matemática-Licenciatura. Já 4,5\%, S20, mudou os seus pensamentos, porém, está na área para não ficar desempregado, como trazido no decorrer dessa descrição.

$22,7 \%$ licenciandos que apresentavam pontos positivos na primeira pergunta a respeito da docência. Dentre esse número, 9,1\% mudaram as suas visões, S4 e S9. O discente S4 pensava que à docência seria um campo fácil, por gostar de interagir com pessoas, porém, em meio à prática de ensino, experienciação, essa visão mudou. Como apresenta a sua resposta: "Mudou completamente. Depois de ver e ter experiências na área, percebi que não adianta só saber ou gostar da matemática é necessária uma metodologia uma didática adequada para facilitar a aprendizagem do aluno.”. E, S9 pensava a docência como um campo de experiência continuo, em que na atualidade traz: "Mudou muito, afinal são poucos os professores dispostos a ensinar, e hoje não me sinto tão preparada para lecionar." Esse sujeito traz em discussão a realidade de nossa educação, onde muitos professores não ensinam e quando ensinam é de forma limitada, onde não aprofundam os conteúdos, na busca de apresentar um leque de possibilidades dos alunos aprenderem. Outro ponto importante em sua fala, é que não se sente preparado para lecionar. Realmente, nunca estaremos, pois vamos aprendendo a estar professor ao longo do tempo, em meio ás praticas. Onde essa aprendizagem é contínua, que nos constituem como professores, apresentando faces provisórias ao nosso devir.

$31 \%$ dos alunos quando responderam a primeira pergunta, trouxeram as dificuldades que atravessam os docentes, no mesmo instante que salientaram a importância, Ihe atribuindo qualidades. Por isso, receberam a nomeação de respostas em partes (tabela 2). E 9,1\% dos alunos que trouxeram pontos em partes na resposta da primeira pergunta mudaram as suas visões, em que atualmente percebem que podem contribuir com a aprendizagem dos alunos e no ambiente universitário permite se deparar com as especificidades que carregam todos os cursos. Além disso, dessa porcentagem, podemos destacar as visões de $\mathrm{S} 12$, onde o mesmo apresenta que durante os estágios supervisionados, notou certa distância entre a prática e a teoria, em que ressalta que cabe ao professor querer fazer diferente. Sendo assim, o que mais the preocupa é que cada dia os alunos estão mais atualizados, conectados. Assim, o mesmo acredita que a formação não é suficiente para abranger os alunos do presente século, trazendo que o professor deve buscar meio além da sua formação para suprir as necessidades desses alunos. Como apresenta a sua resposta: "A mesma. O que me preocupa é que a cada dia a clientela está mais 
atualizada, conectada. Pois seremos professores de alunos que ainda nem nasceram. Então o professor deve buscar meios além de sua formação para supriras necessidades desses alunos (pois essa formação não é suficiente para tal).”.

Com isso, ele aponta um fator essencial, o qual é acorrentado no referencial teórico desta pesquisa, que o dispositivo curso de matemática não "forma" professor para enfrentar qualquer situação na sua trajetória, no seu devirprofessor. Os acontecimentos nas salas de aulas são imprevisíveis e toda turma possui a sua especificidade, multiplicidade. Outro ponto importante, é que o mesmo traz os avanços tecnológicos, o acesso à internet como um desafio na docência, que requer que o professor aprofunde buscando meio de trabalhar, de enfrentar, de utilizar nasala de aula.

Os alunos que adentraram ao curso por pensar que era apenas ensinar o conteúdo, ou seja, possuía visões abreviadas sobre a docência, todos modificaram as suas visões. Hoje entendem que ser professor é mais afundo, precisa se preocupar com aprendizagem dos alunos, adequar os conteúdos com as práticas de ensino.

Com isso, 54,5\% mudaram as suas visões em relação à docência estando no dispositivo curso de Matemática-Licenciatura. Uns apresentaram pontos positivos e outros destacaram as dificuldades que permeia a profissão de professor. Passando a descrição dos dados para a quarta pergunta, "O que você mais admira em um/uma docente de matemática." Percebe-se, de maneira geral, que os discentes admiram os docentes que se preocupam com a aprendizagem dos seus alunos, a forma que ensina os conteúdos para os mesmos, ou seja, a metodologia e didática. Os professores que optam por ser diferentes, que gostam de ensinar, dialogam com seus alunos e possuem relações interpessoais.

Cada discente possui uma maneira diferente de olhar à docência, sendo assim, as suas respostas são reflexos dos requisitos do que um professor precisa ter para "ser" um excelente profissional. Onde esses requisitos foram constituídos ao longo de seu devir professor, fora e dentro do dispositivo curso de matemática, porque todos carregam um pouco dos professores que os perpassaram, retendo os que consideram "bons", e descartando as marcas negativas. No entanto, existem aqueles que reproduzem essas marcas negativas em suas turmas, ou seja, acabam usando as mesmas armas de subjetivações pela qual foi subjetivado "negativamente". Por isso a necessidade de refletirmos qual professor gostaria deter, e tornamo-lo. Isso precisa ser uma incessante reflexão, pois às vezes queremos ensinar os alunos da forma que aprendemos e, às vezes, isso os limita.

A tabela 3 a seguir, representa os requisitos (categorizações) convergentes encontrados nas respostas dos alunos, sobre os que eles mais admiram nos professores de matemática. 
Tabela 3 Amostra do que os alunos mais admiram em um/uma docente de matemática

\begin{tabular}{c|c|c}
\hline $\begin{array}{c}\text { Categorias (admirações } \\
\text { do docente) }\end{array}$ & Sujeitos & $\begin{array}{c}\mathbf{N}^{\circ} \text { de } \\
\text { licenciandos por } \\
\text { categoria }\end{array}$ \\
\hline Aprendizagem & $\mathrm{S} 1, \mathrm{~S} 2$ & 02 \\
\hline $\begin{array}{c}\text { Conhecimento/Domínio } \\
\text { do conteúdo }\end{array}$ & $\mathrm{S} 2, \mathrm{~S} 5, \mathrm{~S} 6, \mathrm{~S} 7, \mathrm{~S} 8$ & 05 \\
\hline Didática/ Metodologia & $\mathrm{S} 4, \mathrm{~S} 6, \mathrm{~S} 7, \mathrm{~S} 8, \mathrm{~S} 15$, & 09 \\
\hline Qualidades & $\mathrm{S} 4, \mathrm{~S} 5, \mathrm{~S} 6, \mathrm{~S} 9, \mathrm{~S} 10$, & 02 \\
\hline Ensinar os Conteúdos & $\mathrm{S} 2,26$ & 03 \\
\hline $\begin{array}{c}\text { Diálogos e Relações } \\
\text { Interpessoais }\end{array}$ & $\mathrm{S} 4, \mathrm{~S} 8, \mathrm{~S} 21$ & 05 \\
\hline $\begin{array}{c}\text { Vontade de exercer a } \\
\text { profissão }\end{array}$ & $\mathrm{S} 5, \mathrm{~S} 9, \mathrm{~S} 10, \mathrm{~S} 11, \mathrm{~S} 13$ & 01 \\
\hline Opção de ser diferente & $\mathrm{S} 12$ & 01 \\
\hline $\begin{array}{c}\text { Formação Moral e } \\
\text { Acadêmica }\end{array}$ & $\mathrm{S} 19$ & \\
\hline
\end{tabular}

Fonte: Acervo da pesquisa (2020).

Sendo assim, entre essas categorizações as que mais integram a maior parte das concepções dos discentes, são: "Qualidades", que apresenta os afetos/sentimentos que os professores precisam ter e a Didática/Metodologia, que são as formas de transmitir os conteúdos. Entrelaçando as respostas que apresentam essas duas categorizações conjuntamente, temos:

S4. A paciência, a metodologia do professor (a). Quando o mesmo se coloca no lugar do aluno e abre espaços para dialogar.

S6. A forma em que tenta explicar aos alunos que estão com dificuldade. Paciência, a simplicidade; E quando sabe dominar o que ensina.

O atributo paciência é apresentado em ambas às respostas, além da metodologia, forma de explicar os conteúdos. Subtendemos pela resposta de S6 que sua maior preocupação é com os alunos que possuem dificuldades. 
Movimentando-se pelas respostas, encontramos os discentes que reforçam unicamente a categoria "Didática/metodologia", são eles: S15, "Na metodologia, pois existem alguns docentes que facilitam o raciocínio dos estudantes.", S16 "Tenho admiração pela maneira que o professor apresenta determinado conteúdo, as formas diferentes que ele mostra ao aluno." S22, "O jeito dinâmico de trabalhar os conteúdos.". Desta forma, eles admiram professores que oferecem uma série de possibilidades por meio de suas aulas, tendo os alunos como foco principal, na busca de diminuir as dificuldades que os mesmos enfrentam. Essa série de possibilidades não está ligada simplesmente as variedades de conteúdos, ou seja, para cada conteúdo, trabalhar com uma metodologia diferente. Mas, na diversidade de forma que possui para se passar o mesmo conteúdo. Exemplo, quando surge alguma dúvida por parte dos alunos, o professor procura outro caminho de explicar o mesmo conteúdo.

Dessas compreensões imagina-se que S16 admira professores que trabalham pela perspectiva inclusiva, amarrada com as diversas formas de aprender. Isso é um passo para trabalhar a multiplicidade nas aulas, olhando que os alunos aprendem de formas diferentes e, caso não consigam acompanhar uma determinada prática de ensino, o professor geralmente possuir um plano $B$, outra possibilidade. Porém, para isso é necessário mergulhar nos conteúdos, pesquisar mais. "Ser" (estar) um professor da diferença, da multiplicidade, exige bastante esforço e estudos.

Da resposta de $S 22$, percebe-se que o mesmo admira professores que saem do tradicionalismo, isto é, os que inovam as suas aulas. Esse dinamismo que ele cita, poderia ser jogos matemáticos, materiais manipuláveis e lúdicos, brincadeiras, entre outros. Sendo que nem sempre dá para trabalhar de forma lúdica.

Prosseguindo com as descrições das respostas, vê-se que fora as qualidades citadas, os licenciandos admiram professores compreensivos, humildes, determinados, criativos. Nota-se, que essas estão encadeadas com a didática/ metodologia. Por que se um professor é criativo, logo procura sempre que pode do comodismo e traz aulas inovadoras.

Além das metodologias, alguns licenciandos reforçam o domínio dos conteúdos matemáticos, as relações interpessoais. Como é caso de S8, "As metodologias, a disciplina, as relações interpessoais e o domínio (segurança) no que está fazendo." Essas relações interpessoais aparecem na categorização "Diálogo/Relações interpessoais", igualmente a S4, que já foi aludido, que admira quando os professores abrem um espaço para dialogar. E ter segurança do que está ensinando recai na mesma tecla, o professor precisa ter um aprofundamento dos conteúdos.

Conduzindo-se entre as respostas, tem-se que um professor de matemática que domina os conteúdos, é admirável. Como mostra a resposta de 
S2, "Quando o docente demonstra o domínio do que está ensinando ou transmitindo. Além, da preocupação com os alunos, se realmente estão aprendendo." Nessa acepção, o professor precisa também constatar, se os alunos estão aprendendo, em prol de melhorar, ou seja, se autoavaliar. Assim, ele não estabelece a visão de um professor fixo, mas inconcluso, indeterminado. S1, "Quando o docente se preocupa com a aprendizagem de seus alunos. Quando ele não se dá por satisfeito até saber que seus alunos aprenderam tal conteúdo". Com isso, nota-se, que $\mathrm{S} 1$ apresenta argumentos na mesma lógica de S2. Eles admiram os professores que focam na aprendizagem dos alunos.

S12 admira os docentes que optam ser diferentes, que atravesse os discursos negativos que a profissão de professor perpassa, por ser algo desvalorizado pela sociedade e, também os que atravessam os discursos voltados a matemática, que a classifica, muitas vezes, como coisa de "doido".

S19 traz que a admiração pelo professor de matemática "[...] é relativo, pois o docente, sua postura depende muito da formação moral que, este teve e tem durante a vida social no todo e também a formação acadêmica conta muito.". Assim, ele apresenta a formação acadêmica, que deu a entender, que a universidade contribui para a formação moral do professor, em conjunto com a sua vida social. Como trazido no capítulo 3 , às linhas de forças que permeia a formação de professores subjetivam os alunos através das linhas de pesquisas, formas de pensamentos, discursos.

Contudo, os requisitos que os licenciandos admiram nos professores são reflexos das suas visões em relação à docência, os quais foram constituídos ao longo das suas experiências no mundo acadêmico e nas práticas de ensino, pois mediante a média dos semestres que os discentes estão inseridos, imagina-se que as maiorias tiveram contato com turmas na Educação Básica, no mínimo por meio dos estágios supervisionados.

Na quinta e última pergunta a ser destrinchada, Como e Onde você se imagina lecionando Matemática daqui a cinco anos? Permite-nos perceber o que os licenciandos traçaram para o seu futuro, conjuntamente, algumas subjetivações e agenciamentos ocultos. Seguidamente, apresentamos a tabela 3.

Tabela 4 Distribuição dos licenciandos conforme onde se imaginam lecionando daqui a 5 anos

\begin{tabular}{l|c|r}
\hline \multicolumn{1}{c|}{ Unidade de Ensino } & \multicolumn{2}{c}{$\mathbf{N}^{\circ}$ de licenciandos (n\% \%) } \\
\hline Ensino superior & 04 & $18,2 \%$ \\
\hline & & \\
Educação Básica/ Ensino superior & 02 & $9,1 \%$ \\
\hline
\end{tabular}




\begin{tabular}{l|c|c}
\hline $\begin{array}{l}\text { Educação } \\
\text { Básica }\end{array}$ & 05 & $27,2 \%$ \\
\hline $\begin{array}{l}\text { Educação básica/ cursinho } \\
\text { preparatório/ETE }\end{array}$ & 01 & $4,5 \%$ \\
\hline $\begin{array}{l}\text { Qualquer Unidade de Ensino } \\
\text { Não deseja lecionar/outra profissão }\end{array}$ & 07 & $31,8 \%$ \\
\hline & 02 & $9,1 \%$ \\
\hline Total & 22 & $100 \%$ \\
\hline
\end{tabular}

Fonte: Acervo da pesquisa (2020).

Conforme a tabela $4,31,8 \%$ dos alunos não delinearam a unidade de ensino que desejam lecionar, realçaram que independentemente do local, se sentindo bem, com salas de aulas com mais recursos disponíveis e com alunos que querem aprender. Utilizando de metodologias adequadas, de forma que sejam significativas para os alunos. Levando para a sala de aula o que aprendeu no dispositivo curso de Matemática-Licenciatura. Como mostra algumas respostas dessa porcentagem, a seguir:

S5. Independente da instituição de ensino, me sentindo a vontade e com vontade de exercer a profissão professor de Matemática.

S7. Uma professora segura, com uma boa didática e metodologia para lecionar em minhas turmas.

S10. Em uma sala com mais recursos disponíveis e alunos que querem aprender de verdade.

S19. Espero levar o melhor do que aprendi durante os anos de formação e, também, o que desaprendi com certos professores que tive durante minha vida escolar/acadêmica. Com eles eu posso dizer que aprendi a como me portar em sala de aula.

Nota-se que essas respostas são complementares as que foram dadas a quarta questão. Segundo elas, esses discentes ecoam qualidades que os professores precisam ter, como: a segurança naquilo que está ensinando, com adequação das práticas de ensino, com condições de trabalho. Quando S10 ressoam o desejo de ter alunos que querem aprender de verdade, imagina-se, que o mesmo acredita em dias melhores no mundo da educação, que na atualidade está encoberto pelo mar de desinteresse. Além disso, traz em contexto os pensamentos de muitos professores, que desejam ensinar alunos que anseiam aprender, e não aos alunos difíceis, que são os que necessitam de 
fato da nossa ajuda. Assim, supõem-se que os professores têm a cultura de criar a estrutura de aluno "ideal" e planeja as aulas em volta deles, prejudicando os que não possuem o mesmo oficio.

Da resposta de S19, percebe-se, que o mesmo se sente preparado para enfrentar qualquer situação comparecida na sala de aula, em que isso é reflexo da formação de professores, o qual o mesmo salienta que levará o melhor que aprendeu durante a sua formação acadêmica.

A formação de professores lança um perfil de professores "ideais" para Educação Básica, dando a entender que o dispositivo curso de MatemáticaLicenciatura, transforma/molda 0 aluno-escolar e os tornam alunosuniversitários, para depois sair o resultado "definitivo" professor de matemática. Como se fossem completos em si mesmo. No entanto, estar professor é algo incessante que precisa ser renovado todos os dias, algo de constituição continua, em que numa turma estar um, em outra já estar outro. Em cada sala de aula, em cada encontro, descrevem uma página do seu devir professor.

Infelizmente esse pensamento não se estende a todos os professores, pois a aqueles que se acham completos, estacionados, e reproduzem os mesmos planejamentos utilizados durante um intenso período de tempo. Como se os alunos fossem sempre os mesmos.

Ainda sobre esse percentual, temos os discentes que não costuma refletir sobre o futuro, como é o caso de S9, que alega: "Sinceramente não sei, não costumo pensar muito no futuro." Se formos novamente atentar a média dos semestres que esses alunos estão inseridos, nota-se, que falta pouco para esses alunos finalizar o curso. Temos também o caso de S20 que reafirma o que ele trouxe em suas demais respostas, que está no curso como segunda opção. Assim, para ele em qualquer lugar que lecionar está bom. Isso denota o desejo pelo que pode conseguir através da docência.

$9,1 \%$ dos licenciandos não desejam lecionar, aludem à outra profissão. S4 traz que irá fazer concurso da polícia. Caso não consiga, o mesmo gostaria de ensinar no ensino médio. E S14 não se vê lecionando daqui a cinco anos. Será que a sua permaneça está voltada aos auxílios que recebe? Com isso, pressupõe-se que eles não foram agenciados pela profissão de professores, os quais se imaginam atuando em outra profissão. Isso mediato, muitas vezes, quando pretendem fazer provas de concursos a nível superior.

Em contrapartida, $18,2 \%$ desejam alçar voos mais altos almejando lecionar no dispositivo-faculdade, ou ao menos estar próximo de docentes universitários, ou seja, eles foram agenciados, convidados a estar no âmbito acadêmico, não apenas como alunos. Todavia, adentramos em alguns dispositivos como alunos e em outros como professores, por exemplo, estudar pós-graduação e "ser" (estar) professor substituto, realidade de muitos sujeitos que estão na UFPE. Conforme as respostas S1, S2, S21, S22: 
S1. Imagino está lecionando em uma faculdade ou pelo menos está próxima de um ser docente em uma faculdade.

S2. Em uma Universidade Federal, atuando na educação matemática.

S21.Lecionando disciplinas da educação ou ensino de matemática em centros universitários (Se possível).

S22. No ensino superior.

Desses que se imaginam lecionando na universidade supõe-se que eles irão prosseguir com os seus estudos, em busca de adentrar em cursos de pósgraduação. Por enquanto, se eles resolvem reterritorializar para onde receberam a atribuição do título de professor, para a UFPE.

A resposta de $S 2$ apresenta um desejo bem traçado, conhece os seus desejos. O mesmo atua na educação básica e pretende entrar em outros dispositivos. Sendo assim, ele foi agenciado pelos encontros na universidade, e deseja atuar precisamente na educação matemática, como é o caso também de S22. De maneira geral, essa percentagem faz surgir em nós alguns outros questionamentos: Por que eles preferem o Ensino Superior, já que a sua formação está voltada para Educação Básica? Será que é por causa das dificuldades que atravessam o dispositivo-escola, que tem provocado grande desencanto entre os professores?

9,1\% dos licenciandos desejam atuar na Educação Básica e/ou talvez no Ensino superior. Desse percentual, frisamos as respostas de S3 e S8 que apresenta respectivamente: "Sendo uma das melhores professoras de matemática da minha cidade e está lecionando em uma faculdade", "Gosto muito do ensino básico, porém se houver a possibilidade de alçar voos maiores não sei se hesitaria.". Então, percebe-se que os mesmos desejam atuar na profissão e da resposta de S8, vê-se que o mesmo foi agenciado pela Educação Básica, ficando em dúvida se aceita, no momento que surgir, as oportunidades de lecionar no ensino superior. Dessa acepção, tem-se que muitos desejam lutar no dispositivo escolar, a fim de contribuir com a melhoria, na busca de provocar, criar encontros, para que ocorra de fato ensino-aprendizagem.

$27,2 \%$ dos sujeitos imaginam-se lecionando em escolas, ou seja, na Educação básica. Onde algumas das respostas que compõe esse índice, não estabeleceram os graus de ensino exatos, que desejam lecionar. Há aqueles que desejam reterritorializar para o dispositivo-escola de onde adentrara. De acordo com as respostas logo após:

S6. Gostaria de ensinar em uma das escolas que estudei durante o Ensino Fundamental. E espero ser [uma] professora 
que busque cativar os alunos, com aulas dinâmicas e que tenham utilidade na vida dos alunos.

S12. Me imagino em uma escola da zona rural na qual estudei o ensino fundamental, é onde eu gostava de estar.

S15. Como não pretendo fazer mestrado, [imagino-me] em um colégio de referência de ensino médio.

Das respostas de S6 e S12, compreende-se que os mesmos pretendem reterritorializar para as escolas que estudaram durante o Ensino Fundamental. Se for possível, o seu regresso será não mais como alunos, mas como docentes. Vê-se que eles foram agenciados pelo dispositivo-escola, a ponto de querer retornar, tiveram encontros, marcas positivas.

Além disso, da resposta de S6, trocando o verbo "cativar" por "agenciar", tem-se que a mesma pretende ser um instrumento agenciador dos desejos dos seus alunos, proporcionando aulas dinâmicas, que tenham utilidade na vida deles, ou seja, trazer significância daquilo que está ensinando com o dia a dia dos alunos. S15 não pretende fazer mestrado, dando a entender que a sua "formação" acadêmica é suficiente, conclusa. Diríamos que o curso é um dos passos da constituição do devir professor, que não tem limites para acabar, ao menos que resolvam estacionar.

Tem aquele discente que deseja está estabilizado e concursado, como é o caso de S13: "Em escolas de ensino fundamental e médio, públicas e particulares, concursada e estabilizada.". Que seja uma estabilidade apenas voltada a emprego e, não das aulas. E também, o que idealizou várias possibilidades, como foi o leque apresentado por $\mathrm{S11}$, conforme a sua resposta: "Em algum curso superior (principalmente matemática), curso preparatório ou ensino regular em escolas (ETE).".

No mais, a maioria dos licenciandos não definiu a Unidade de Ensino que se imaginam atuando daqui a 05 anos, porém encontramos aqueles que possuem os seus desejos bem focados no ensino superior, como também encontramos os que gostariam de reterritorializar no dispositivo-escola de onde saiu, a que eles estudaram. De modo geral, percebe-se que $90,9 \%$ foram subjetivados/agenciados a desejar atuar na profissão de professores.

\section{CONSIDERAÇÕES FINAIS}

Foi realçado que o devir docente dos licenciandos no dispositivouniversidade de Matemática-Licenciatura é uma multiplicidade, constituído ao longo das experiências, das marcas, dos encontros. Onde muitos adentram no mesmo não pela docência em si, mas pelo que podem conseguir por meio dela. Com isso, de forma geral, os processos de subjetivações visíveis que levaram 
os sujeitos dessa pesquisa desejar ingressar no referido dispositivo, foram: falta de opção; baixa concorrência, à docência em si; o gosto pela disciplina; subjetivações e agenciamentos advindos de professores (escolar e cursinho) e familiares; facilidade de arrumar um emprego.

Assim, mesmo que sempre são preenchidas as vagas no curso de Matemática-Licenciatura todos os semestres, em massa, os sujeitos ingressantes não levam em consideração a profissão de professores, a importância da mesma para sociedade. Com isso, mesmo que não seja um desejo a priori dos sujeitos, os mesmos são subjetivados a desejar cursar, pois caso contrário, passaram um ano sem estudar, sem estar num curso superior, em que na sociedade impõe-se que todos os sujeitos precisam estar vinculados a algumas instituições de ensino.

Além disso, trouxe-nos, que mesmo que as subjetivações recebam categorizações, da maneira que foi descrita no primeiro parágrafo das considerações, temos que as mesmas atravessaram os sujeitos de forma diferente, pulsando que um fator que desvia os seus desejos para rotas diferentes é atrelado, subjetivado pela vida particular, devir, singularidade de cada discente, em que muitos, desistiram de cursar engenharia, porque precisavam trabalhar durante o dia; porque não conseguiram entrar de primeira, e se colocaram como incapaz de conseguir nas demais tentativas, etc.

\section{REFERÊNCIAS}

BRÍGIDO, E. I. Michel Foucault: Uma análise do poder. Rev. Direito Econ. Socioambiental, Curitiba, v. 4, n.1, p.56-75, jan./jun.2013.

CORAZZA, S. M. O docente da diferença. In: IV Colóquio Luso Brasileiro sobre Questões Curriculares e VIII Colóquio sobre Questões Curriculares. UFSC, Florianópolis, 2, set. 2008.

COSTA, L. R. S. Os reflexos dos discursos sócio-culturais sobre a disciplina de matemática. Caruaru: 2017 (TCC).

DELEUZE, Gilles. ¿Que és um dispositivo? In: Michel Foucault, Filósofo. Barcelona: Gedisa, 1990, PP. 155-161. Tradução de wanderson flor do nascimento. Disponível em: http: //escolanomade.Org/pensadores-textos-e-videos/deleuze-gilles/o-que-e-umdispositivo. Acesso em: 01 de ago. de 2018.

DELEUZE, Gilles. Désiretplaisir. Magagazine Littéraire. Paris, n. 325, oct, 1994, pp.57-65.

DELEUZE, Gilles. PARNET, c. Diálogos. Trad. Eloisa Araújo Ribeiro, São Paulo: Escuta, 1998, 184p.

FISCHER, R. M. B. Foucault e a análise do discurso em educação. Cadernos de Pesquisa. Rio de Janeiro, n. 114, p. 197-223, 2001. 
FOUCAULT, M. A arqueologia do saber. 7. ed. Rio de janeiro: Forense Universitária, 2008.

GALLO, S. O que é Filosofia da Educação? Anotações a partir de Deleuze e Guattari. Florianópolis, v.18, n34, 2000.

GUATTARI, F; ROLNIK, S. Micropolítica: Cartografias do desejo. 4 ed. Petrópolis: Vozes, 1996.

HEINEN, S. V. I. HEINEM, S. L. I. As filosofias da diferença de Nietzsche e de Deleuze: para construir outros modos. In: Linha Mestra, n. 23, ago. Dez. 2013. Disponível em:

https://linhamestra23.files.wordpress.com/2013/12/03_para_uma_escrita_delirante_as filosofias_da_diferenca_heinen_heinen.pdf. Acesso em: 20 de dez. 2018.

LEMOS S. C. F. Diferença e Educação: um diálogo com Hélio Rebello Cardoso JR. In: Revista do Difere, v.1, n.2, dez. 2011. INSS 21796505.

LEVY, Tatiana Salem. O fora como o (não-) espaço da literatura. In: BRUNO, Mário \& QUEIROZ, André \& CHRIST, Isabelle. Pensar de outra maneira a partir de Claudio Ulpiano. Rio de Janeiro: Pazulin, 2007.

MANSANO, Sônia Regina Vagas. Sujeito, subjetividade e modos de subjetivação na contemporaneidade. Revista de Psicologia da UNESP, 8(2). 2009.

MARCELLO, A. F. O conceito de dispositivo em Foucault: mídia e produção agonística de sujeitos. In: Educação e Realidade, v.29, n.1, 2004, pp. 199-2011.

MURAD, G. F. M. O sujeito em Foucault. Rio: 10, ago. 2010.

QUEIROZ, S. M. Movimentos que permeiam o devir professor de matemática de alguns licenciandos. 2015. 208f. Tese (Doutorado em Educação Matemática) Instituto de Geociências e Ciências Exatas, Universidade Estadual Paulista, Rio Claro, 2015.

QUEIROZ, S. M. A educação em meio ao Hiperativismo sócio-cultural do mundo líquido. In: X Encontro Nacional de Educação Matemática. São Paulo, SP. 2016a .

ROLNIK, S. Pensamento, corpo e devir: uma perspectiva ético/estético/política no trabalho acadêmico. In: Cadernos de Subjetividade n². São Paulo: PUC, 1993.

SALLES, Márcio. Foucault e os dispositivos. In: IX Jornadas de Sociologia de la UNLP. Dez. 2016.

SCHOPKE, R. O conceito de "Diferença” na obra de Gilles Deleuze. Rio de janeiro, 2009. Disponível em: https://rogsil.wordpress.com/2009/11/22/o-conceito-de-diferencana-obra-de-gilles-deleuze/. Acesso em: 20 ago. 2018.

SOUSA, C. N. MENEZES, T. N. B. A. O poder disciplinar uma leitura em vigiar e punir. In: SABERES, Natal - RN, v.1, n.4, jun. 2010.

TARTARO, F. T. CAVAMURA, B. R. N. SOUZA, C. C. A. Por que a universidade não forma um professor de matemática? Repositório Institucional UNESP. Rio Claro: 2014. ISSN2357-7819-2014-2839-2849. 
Disponível em: https://repositorio.unesp.br/handle/11449/141662?localeattribute=pt_BR. Acesso em: 28 jan. 2019. 